\title{
Role of Governance in Explaining Domestic Investment in Nigeria
}

\author{
Olusegun Ayodele Akanbi ${ }^{1}$
}

Working Paper Number 168

\footnotetext{
${ }^{1}$ Department of Economics, University of Pretoria, South Africa
} 


\title{
Role of Governance in Explaining Domestic Investment in Nigeria
}

\author{
Olusegun Ayodele Akanbi*
}

March 30, 2010

\begin{abstract}
This study empirically examines the pattern of domestic investment that is consistent with a neoclassical supply-side model of the Nigerian economy. The estimations are carried out with time-series data from 1970 to 2006 using the Johansen estimation techniques. The results conform to the findings of existing literature that real output, user cost of capital, and the level of financial development are significant determinants of domestic investment in Nigeria. The distinctive feature of the study is the significant role played by governance in explaining the longterm pattern of domestic investment in Nigeria. The results from the long-run estimation and the impulse responses revealed that a well-structured and stable socio-economic environment will boost domestic investment over the long run. Therefore, in modelling domestic investment for Nigeria, it is imperative to incorporate the significant role played by governance.
\end{abstract}

Keywords: Investment; Governance;Nigeria

JEL Classifications: E22;E21;G39

\section{Introduction}

Empirical evidence has revealed that investment is one of the major determinants of sustainable long-term economic growth. In recent years, there has been mounting debate about the importance of domestic investment to economic development especially in developing economies. According to OECD: 2001, a country's economic performance over time is determined to a large extent by its governance performances (i.e. political, institutional, and legal environment). It is generally accepted that long-term economic growth of a country will lead to a significant improvement in the standard of living of its citizens. A reduction in the widespread poverty which is a major feature of the Nigeria economy can be achieved through a sustained increase in domestic investment.

A closer look at the pattern of domestic investment in Nigeria is imperative in order to be able to achieve sustained growth. Over the years, the Nigerian economy has gone through periods of economic and political instability, which have hindered domestic investment into the country. The stability of a country's socio-economic and political system reflects the soundness of its level of governance and this is seen as a major factor in decision-making by investors.

The role of good governance in growth has been a central debate among global policy makers in recent years. The major stumbling block to the implementation of many macroeconomic policies in the developing and low-income economies has been the absence of the political 'will' imbedded within the leadership structure. The extent to which a country's governance can impact on the socioeconomic environment and productive capacity cannot be underestimated (Globerman \& Shapiro, 2002).

The concept of governance as used in this study consists of the traditions and institutions by which the authority of a country is being exercised (WGI, 2008). This includes the effectiveness

*Department of Economics, University of Pretoria, South Africa 
of government in formulating and implementing sound policies, the respect for the rule of law, the state of the institutions that govern against corrupt practices, and the stability of the political environment. These elements of governance will affect the investment decisions of firms directly.

This study, however, augments the existing literature on the determinants of domestic investment in the context of the Nigerian economy. It investigates the important role of the political environment in explaining long-term domestic investment in Nigeria.

The rest of the study is organised as follows; Section 2 presents some stylised facts on the evolution of domestic investment in Nigeria. Section 3 presents the empirical analysis, which contains the background on the existing related literature, theoretical framework, methodology and the description of the data used in the study. It also presents the estimation results. Section 4 concludes the study.

\section{Stylised Facts}

This section presents the evolution of domestic investment in Nigeria since 1970. A few basic trends have emerged over the past few years with regards to the pattern of growth in domestic investment and the ratio of domestic investment to Gross Domestic Product (GDP).

Figure 1, shows the growth in domestic investment and investment as a ratio of GDP in Nigeria. The average growth rate of domestic investment since 1970 is about 11 percent, while GDP grew by about 7 percent over the same period. This resulted in a higher investment-GDP ratio on the average of about 20 percent due to the denominator effects of GDP.

Though highly unstable, growth in domestic investment was positive over most of the period since 1970. Between 1970 and 1977, domestic investment grew by about 41 percent on average, reaching a record high of about 118 percent in 1973. Growth averaged about 23 percent between 1985 and 1993. The highly unstable pattern of growth in domestic investment in Nigeria can be attributed to the volatile economic and political environment in the country (Globerman \& Shapiro; 2002). Therefore, in modelling investment in Nigeria, it is necessary to incorporate the significant role of good governance.

\section{Empirical Analysis}

\subsection{Background}

There is a large body of literature that has modelled the investment behaviour of countries across the world. These studies have adopted various investment models such as the accelerator model, the cash-flow model, Tobin's Q model; and the neoclassical model (Jorgenson approach), which differ according to the various assumptions on which the models rest. The important role of governance in determining the level of investment is, however, under-explored in the literature. Most studies on the determinants of investment (i.e. Shafik (1992), Oshikoya (1994), Ghura and Goodwin (2000), Ndikumana (2000), Du Toit and Moolman (2004), and Bayraktar and Fofack (2007)) have focused on macroeconomic and financial variables while ignoring the role played by policy and institution.

An empirical model of private investment that takes into account the major features of a developing country is investigated in Shafik (1992). Using the cointegration and error-correction techniques under a neoclassical framework of profit-maximising and cost-minimising behaviour of firms, the results suggest that mark-up prices, internal financing of firms and the cost of investment goods are the major determinants of private investment in Egypt.

The important role played by macroeconomic and financial variables as determinants of domestic investment in Sub-Saharan Africa (SSA) is investigated by Oshikoya (1994) and Ndikumana (2000). Evidence from their panel data estimates shows a positive and significant relationship between domestic investment and the various indicators of financial development and macroeconomic variables. 
Similar results were found in Ghura and Goodwin (2000) who investigate the determinants of private investment in Asia, Sub-Saharan Africa? and Latin America.

Bayraktar and Fofack (2007) derive a formal specification of a private investment function in Sub-Saharan Africa. Using the Tobin's Q theory and the neoclassical theory of investment, their results point to the significant role played by aggregate profitability shock, and by the financing of investment in determining the level of private investment in Africa.

Du Toit and Moolman (2004) estimate the investment function that is consistent with the neoclassical supply-side model of the South African economy and which allows for profit-maximising and cost-minimising decision making by firms. Their findings reveal the role played by internal and external financial constraints on investment in South Africa. This has been attributed to the various impositions of international sanctions against the country over the years.

Against this background, it is necessary to investigate further other non-macroeconomic and financial variables that have been affecting domestic investment in a typical developing-country context. The importance of the country-specific institutional and political environment as a determining factor in explaining investment has been explored in Altomonte (2000), Bevan and Estrin (2000), and Mody and Srinivasan (1998). Most relevant to this study is the analysis in Globerman and Shapiro (2002), which investigates how governance affects foreign direct investment (FDI) flows in developed and developing economies. Poor governance that is reflected in the unstable political environment in most African countries has been a major hindrance to increasing domestic investment over the years. Following the ideas in Globerman and Shapiro (2002), this study investigates the role of governance in determining domestic investment in Nigeria over the period 1970 to 2006.

\subsection{Theoretical Framework}

The aggregate capital stock at the end of period $t$ is referred to as the net capital stock. A constant depreciation rate $(\delta)$ is assumed. This is expressed as:

$$
K_{t}=(1-\delta) K_{t-1}+I_{t}
$$

Where $K_{t} a n d K_{t-1}$ are the capital stock in the current and previous period respectively, $\delta$ is the rate of depreciation and $I_{t}$ is the gross investment. $\delta K_{t-1}$ is the replacement investment, and net investment $\left(K_{t}-K_{t-1}\right)$ equals total investment minus replacement investment $\left(I_{t}-\delta K_{t-1}\right)$. Therefore, the following identity holds for gross investment:

Gross investment $=$ replacement investment + net investment

The theories of investment behaviour mostly relate the demand for new plant and equipment to the gap between the desired or optimal amount of capital and the actual amount of capital (Du Toit, 1999:81). Combining these two aspects of investment behaviour, gross investment can be written as:

$$
I_{t}=\lambda_{t}\left(K_{t}^{*}-K_{t-1}\right)+\delta K_{t-1}=\lambda_{t} K_{t}^{*}+\left(\delta-\lambda_{t}\right) K_{t-1} .
$$

Where $\lambda_{t}$ is the speed of adjustment between $K_{t}^{*}$ and $K_{t-1}$, and $K_{t}^{*}$ is the desired or optimal capital at the end of the current time period (see Du Toit, 1999:81 for detailed exposition).

As mention earlier, different approaches such as the Keynesian model, the cash-flow model, and the neoclassical model (Jorgenson; 1963 approach) have been used in modelling investment behaviour. The neoclassical model is the most commonly adopted approach in the literature (i.e. Du Toit, 1999; Du Toit and Moolman, 2004; and Pretorius, 1998) in explaining investment decisions of firms. The model is built on the strict assumption that firms maximise profits in a perfectly competitive environment. This study considers an augmented neoclassical approach to be the most suitable approach in estimating the domestic investment function for Nigeria: Unlike the purely neoclassical model, it incorporates institutional characteristics. Therefore, institutional factors such as governance are treated as part of firms' optimisation problem when making investment decisions.

The link between investment and capital stock can be captured empirically either by estimating capital stock and deriving investment subsequently, or estimating investment and the subsequent 
derivation of capital stock (Du Toit, 1999: 91). This study estimates domestic investment, and augments long-run domestic investment in Nigeria with some form of governance indicator, which is modelled together with the level of output, user cost of capital and financial constraint (a measure of financial development). This is presented as:

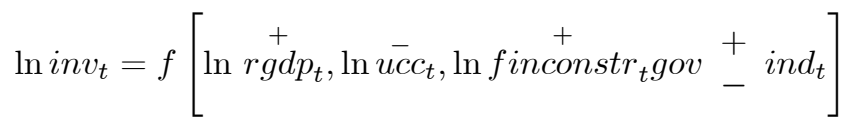

Where $\ln i n v_{t}$ is the natural logarithm of domestic investment in Nigeria; $\ln r g d p_{t}$ is the natural logarithm of real Gross Domestic Product (GDP); $\ln u c c_{t}$ is the natural logarithm of user cost of capital; ln finconstr $_{t}$ is the natural logarithm of financial constraint; and gov_ind $d_{t}$ is the level of governance.

\subsection{Methodology and Data}

This study models the Nigerian domestic investment based on the Jorgenson's neoclassical approach. In line with the Johansen (1988) cointegration estimation technique, the reduced-form Vector Autoregression (VAR) of Equation (3) is re-specified as:

$$
X_{t}=\beta_{0}+\beta_{1} X_{t-1}+\ldots .+\beta_{j} X_{t-j}+\varepsilon_{t}
$$

Where $X_{t}$ is a vector of variables;

$$
X_{t}^{\prime}=\left[\ln r g d p_{t}, \ln u c c_{t}, \ln \text { finconstr }_{t}, \text { gov_ind }_{t}, \ln i n v_{t}\right]
$$

Cholesky decomposition is utilised for orthogonalisation, which means that Cholesky factor is lowered triangular. Therefore, the domestic investment variable will be contemporaneously affected by all the other variables. The need to have a meaningful impulse-response function from the Vector Error Correction Model (VECM) is dictated based on the ordering of the variables.

Based on the long-run relationship that is captured by the domestic investment model specified in Equation (3), a VECM of the following form is estimated to reveal the short-run dynamics in the domestic investment function.

$$
\Delta X_{t}=\pi X_{t-1}+\sum_{i=1}^{p-1} \pi_{i} \Delta X_{t-i}+\varepsilon_{t}
$$

The estimation procedure is as follows. Firstly, the reduced-form VAR in Equation (4) is estimated and all the diagnostic tests are performed. Secondly, the Johansen cointegration test is performed and the cointegrating vectors and loading matrices are identified. Thirdly, a VECM from Equation (6) is estimated and the entire range of diagnostic tests is performed. Lastly, impulse-response analysis is performed ${ }^{1}$.

Data were obtained from the IMF (International Financial Statistics), the World Bank database (African Development Indicators, World Development Indicators, Worldwide Governance Indicators), and the Central Bank of Nigeria Statistical Bulletin. Annual data series which cover the period 1970-2006 were used to estimate the parameters of the model and, where appropriate, the variables were transformed into real figures using the GDP deflator (2000=base year). Graphical exposition of all the data used in the study and their order of integration are presented in the Appendix.

Due to lack of availability of some time series data, the following time series had to be derived for the variables used in the model:

\footnotetext{
${ }^{1}$ All the diagnostic tests performed are presented in the Appendix.
} 


\subsubsection{User Cost of Capital}

In the absence of corporate tax data and a truly long-term yield, a proxy for the user cost of capital was created through an exchange-rate adjusted (since most of the investments are from abroad and an exchange rate is a signal to investors of country risk) prime lending rate of return. This is represented as:

User cost of capital $=(1+\text { interest rate })^{*}$ nominal exchange rate

\subsubsection{Governance Measures}

The worldwide governance indicators developed by Kaufmann et al (1999a) were utilised in this study as a measure of governance. The indices cover a broad range of policy and institutional outcomes for large number of countries, and include the rule of law, corruption, government effectiveness, regulatory quality, and political instability. These indices are also employed in Globerman and Shapiro (2002) as a measure of governance. In order to capture governance in a broader context, the average value of the five elements in the governance indicators is used as a measure of governance. In addition, since the governance indicators series is only available from 1996 onward, and due to the persistence of governance over time, the average governance score for 1996-2006 is used for all previous years (Akanbi and Beddies, 2008) ${ }^{2}$. The governance scores ranges from -2.5 to +2.5 , with -2.5 representing the worst governance and +2.5 the best governance. Most of the governance scores for Nigeria - and for developing countries - are in the negative range ${ }^{3}$.

\subsubsection{Financing of gross domestic investment (Financial Constraint)}

In a general equilibrium framework (i.e. system of national account), the financing of gross domestic investment equals total gross domestic investment (Du Toit, 1999). Therefore, the financial constraint variable is defined as an identity which enters into the system of equations in the form:

Financial constraint $=$ gross domestic savings + capital flows + changes in reserves + depreciation value

\subsubsection{Rate of Depreciation}

The rate of depreciation can take different values in individual countries, depending on the structure of that particular economy. In general, it is common to assign a higher rate of depreciation to developing or low-income countries. A higher depreciation rate of 20 percent is adopted in this study, since Nigeria allocates much lower revenues to maintenance expenditures (see Bayraktar and Fofack (2007), Beddies (1999), and Vera-Martin (1999)).

\subsection{Estimation Results}

Based on the nature of the Data Generating Process (DGP) of all five variables, an appropriate model for domestic investment in Nigeria is selected and the results of the trace and maximum eigenvalue tests are presented in Table 1. Following the Pantula principle of testing which version of the deterministic component should be used, the trace test identified one cointegrating vector while the maximum eigenvalue test found no cointegration for a model with no trend and intercept in the cointegrating equation.

\footnotetext{
${ }^{2}$ Nigeria had military rule between 1970 and 1996, with the exception of the period 1979-1982. Although these periods features many instabilities (i.e. military coups and ethnic violence), there was a persistence in these instabilities. In other words, there was a re-occurrence of these activities over time and the system of governance did not change.

${ }^{3}$ There has been only a marginal improvement (if any) in governance since 1996, which is the post-military era. These poor elements of governance remain the major features of the Nigerian economy since its independence in 1960.
} 
The long-run part of the VECM is presented in Equation (7). The long-run cointegrating vector identified the domestic investment, which is the equation of interest in this study.

$$
\pi X_{t-1}=\alpha \beta^{\prime} X_{t-1}=\left[\begin{array}{c}
\alpha_{11} \\
\alpha_{21} \\
\alpha_{31} \\
\alpha_{41} \\
\alpha_{51}
\end{array}\right]\left[\begin{array}{llll}
\beta_{11} & \beta_{21} & \beta_{31} & \beta_{41} 1
\end{array}\right]\left[\begin{array}{l}
\ln r g d p_{t-1} \\
\ln u c c_{t-1} \\
\ln \text { finconstr }_{t-1} \\
\text { pi } i_{t-1} \\
\ln \text { inv }_{t-1}
\end{array}\right]
$$

The estimated long-run domestic investment equation is presented in Equation (8) with t-values in parentheses.

$$
\ln i n v_{t}=\underset{(12.97)}{0.95 \ln r g d p_{t}}-\underset{(-2.62)}{0.19 \ln u c c_{t}}+\underset{(-2.78)}{1.86 g o v} i n d_{t}+\underset{(2.62)}{0.17 \ln \text { finconstr }_{t}}
$$

All coefficients are statistically and economically significant and are consistent with the theoretical specification in Equation (3). The results from the core specification confirm that real output, user cost of capital, level of financial development and level of governance are highly significant determinants of domestic investment in Nigeria.

The real output elasticity is consistent with the existing literature and implies a huge positive economic impact of an increase in real output on domestic investment. The results shows that a rise in the cost of financing domestic investment will lead to a fall in the level of aggregate investment in the country, while the level of financial development (i.e. stronger financial system and availability of credit) causes domestic investment to rise. The inclusion of governance performances, which is the distinctive feature of this study, reveals that an investment in a more secure and stable socio-economic environment will attract higher levels of investment spending into the country ${ }^{4}$. The sign and magnitude of the governance indicator is similar to the findings of Globerman and Shapiro $(2002)^{5}$. This result is not surprising, since economic and political instability is one of the major features of the Nigerian economy over the years, and is also a major deterrent to domestic investment ${ }^{6}$. Table 2 presents the short-run adjustment coefficients ( $\alpha$ values or loading matrices) which show the dynamic adjustment towards the long-run equilibrium path. As expected, the $\alpha$ values from the error-correction estimates are all within a 0 to 2 range, implying that all the cointegrating vectors enter into the short-run determination of Nigerian domestic investment and, therefore, they can be regarded as not being weakly exogenous.

The positive sign of the loading factor in governance shows that it tends to push the system away from its long-run equilibrium path. The domestic investment and user cost of capital variables are found to be negative and significant (tending to bring back the system to equilibrium), implying that they play a big role in returning long-run domestic investment back to its equilibrium path.

The graph of the estimated cointegrating relation in Equation (E8) from the VECM is presented in Figure 2 below. The cointegrating relation is found to be appropriate since the graph reverts to the equilibrium (zero).

\subsection{Impulse-response functions}

Based on the dynamic (lag) structure of the VAR, a shock to the i-th variable will affect the $\mathrm{i}$-th variable directly and will also be transmitted to all the endogenous variables in the system. The impulse response reveals the effect of a one-time shock on one of the innovations on current and future values of the endogenous variables. Using the othorgonalised Cholesky decomposition, the impulse responses are derived from the VECM as presented in Figure 3.

\footnotetext{
${ }^{4}$ See Appendix E for robustness check.

${ }^{5}$ This confirms that the governance indicator constructed in this study may be free from any measurement problem.

${ }^{6}$ Governance indicator is not in its natural logarithms due to negative values in the series (see the Appendix for more details).
} 
Figure 3 presents the responses of domestic investment to a one standard deviation shock in the exogenous variables. The response of domestic investment to its own shocks causes an upward revision of the forecast of domestic investment over the 30-year period.

It is expected that investment spending declines as the cost of financing it rises. The cost of capital plays a significant role in the determination of domestic investment, as revealed by a one standard deviation shock in user cost of capital. This led to a permanent fall in domestic investment over the 30-year period.

A one standard deviation positive shock from real output causes domestic investment to rise over the 30-year horizon, while a similar positive effect can be seen as the country's financial system continues to strengthen.

The effect of good governance has also been confirmed from the response of domestic investment as a result of a more stable socio-economic and political environment. A one standard deviation positive shock in governance causes domestic investment to rise over the 30-year period. This indicates the enormous role which good governance plays in sustaining long-term growth in domestic investment.

This confirms the importance of the variables included in the VECM in explaining the movement in domestic investment in Nigeria over the years.

\section{Conclusion}

The aim of this study is to secure a theoretical approach for modelling domestic investment in Nigeria. An augmented neoclassical (Jorgenson) approach was adopted as the most suitable for estimating domestic investment, since it incorporates all cost-minimising and profit-maximising decision-making processes by the firm.

The results from the study confirm that real output, user cost of capital, and the level of financial development are significant determinants of domestic investment in Nigeria. This is in line with the existing literature.

The distinctive feature of this study is the significant role played by good governance in explaining the long-term pattern of domestic investment in Nigeria. The results from the long-run estimation and the impulse responses revealed the fact that a more stable socio-economic and political environment will boost domestic investment over the long-run period. The results suggest that investment in governance structures will attract capital into the country (Globerman and Shapiro (2002).

These results have critical policy implications if an increased productive capacity and improved future growth is to be achieved in the Nigerian economy. Therefore, there is an urgent need to refocus the government's role in certain critical areas of the economy. Government institutions need to be more strengthened by improving coordination within government structures. The political environment must be more secure in order to attract higher levels of private investment. The maintenance of public order, the assurance of property rights, a sound regulatory structure and the creation of a framework that will increase the provision of public goods and services, and the maintenance of infrastructure, is urgent in order to achieve the set macroeconomic objectives.

Future research should attempt to correct some of the shortcomings of this study. The lack of available long-term series on governance rating must be addressed, and this may give a better parameter estimate of the effect of governance on domestic investment.

\section{References}

[1] Akanbi, O.A., \& Beddies, C.H. 2008. Accumulating debt post debt relief: how fast is safe? Forthcoming IMF Working Paper, Washington D.C. 
[2] Altomonte, C. 2000. Economic determinants and institutional framework: FDI in economies in transition. Transnational corporation, Vol.9, No.2, pp.75-106.

[3] Bayraktar, N., and Fofack, H. 2007. Specification of investment functions in Sub-Saharan Africa. World Bank Policy Research Working Paper, No.4171.

[4] Beddies, C.H. 1999. Investment, capital accumulation, and growth: some evidence from Gambia 1964-1998. IMF Working Paper, No.99/117.

[5] Bevan, A., and Estrin, S. 2000. The determinants of foreign direct investment in transition economies. Centre for new and emerging markets, discussion paper, No.9, London Business School, London.

[6] Du Toit, C., and Moolman, E. 2004. A neoclassical investment function of the South African economy. Economic Modelling, Vol.21, pp.647-60.

[7] Du Toit, C.B. 1999. A supply-side model of the South African economy: critical policy implications. Unpublished Doctoral thesis. Pretoria: University of Pretoria.

[8] Ghura, D., and Goodwin, B. 2000. Determinants of private investment: a cross-regional empirical investigation. Applied Economics, Vol.32, pp.1819-29.

[9] Globerman, S., and Shapiro, D. 2002. Global foreign direct investment flows: the role of governance infrastructure. World Development, Vol.30, No.11, pp.1899-1919.

[10] Johansen, S. 1988. Statistical analysis of cointegration vectors. Journal of Economic Dynamics and Control, Vol.12, pp.231-54.

[11] Jorgenson, D. 1963. Capital theory and investment behaviour. American Economic Review, Vol.53, No.2, pp.247-259.

[12] Kaufmann, D., Kraay, A., and Zoido-Lobaton, P. 1999a. Aggregating governance indicators. World Bank Working Paper No.2195.

[13] Mody, A. and Srinivasan, K. 1998. Japanese and U.S firms as foreign investors: do they march to the same tune? Canadian Journal of Economics, Vol.31, No.4, pp.778-800.

[14] Ndikumana, L. 2000. Financial determinants of domestic investment in Sub-Saharan Africa: evidence from panel data. World Development, Vol.28, No.2, pp.381-400.

[15] OECD, 2001. The well-being of nation: the role of human and social capital. OECD Paris.

[16] Oshikoya, T.W. 1994. Macroeconomic determinants of domestic private investment in Africa: An empirical analysis. Economic Development and Cultural Change.

[17] Paruolo, P. 1997. Asymptotic inference on the moving average impact matrix in cointegrated I(1) VAR systems. Economic Theory, Vol.13, pp.79-118.

[18] Pretorius, C.J. 1998. Gross fixed investment in the macroeconometric model of the Reserve Bank. Quarterly Bulletin-March 2002(no.207). Pretoria, South African Reserve Bank.

[19] Said, S. \& Dickey, D. 1984. Testing for unit roots in autoregressive-moving average models with unknown order. Biometrical Vol.71,pp.599-607.

[20] Shafik, N. 1992. Modelling private investment in Egypt. Journal of Development Economics, Vol. 39, pp. 263-77. 
[21] Vera-Martin, M. 1999. Long-run growth in Mali, Niger and Senegal. Unpublished. IMF, Washington D.C.

[22] WGI, 2008. Governance matters. Worldwide governance indicators, available at: http://www.worldbank.org/wgi/governance. 
Figure 1: Growth in Domestic Investment and the Ratio of Domestic Investment to GDP in Nigeria

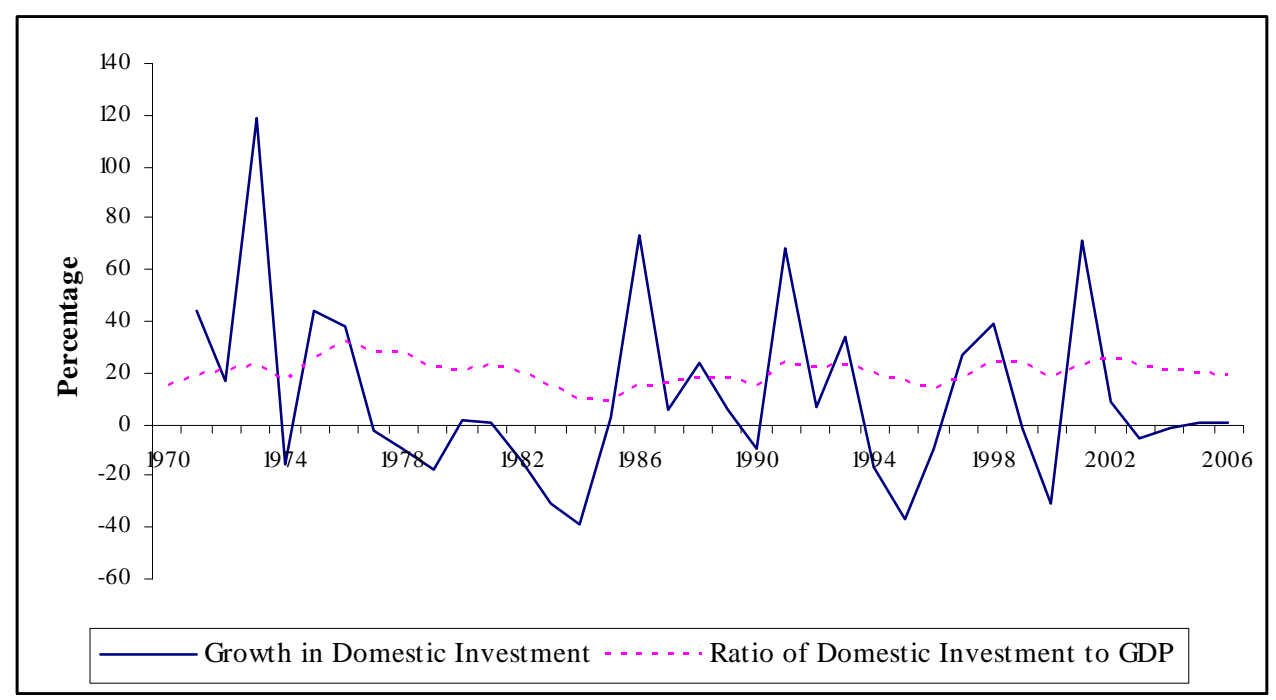

Source: World Bank; World Development Indicators

Figure 2: Cointegrating Relation from VECM

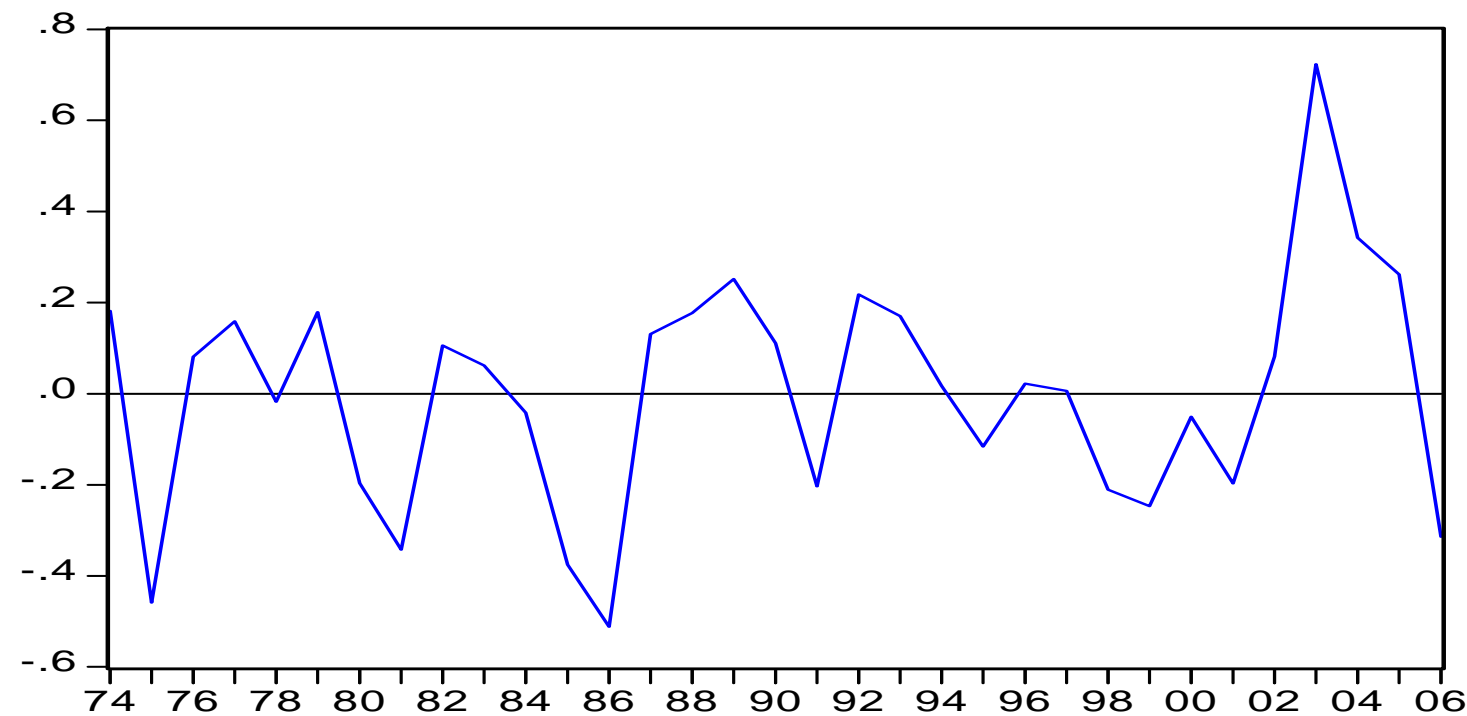

Cointegrating Relation for Domestic Investment Equation 
Figure 3: Response to One Standard Deviation Shock Over a 30-Year Period

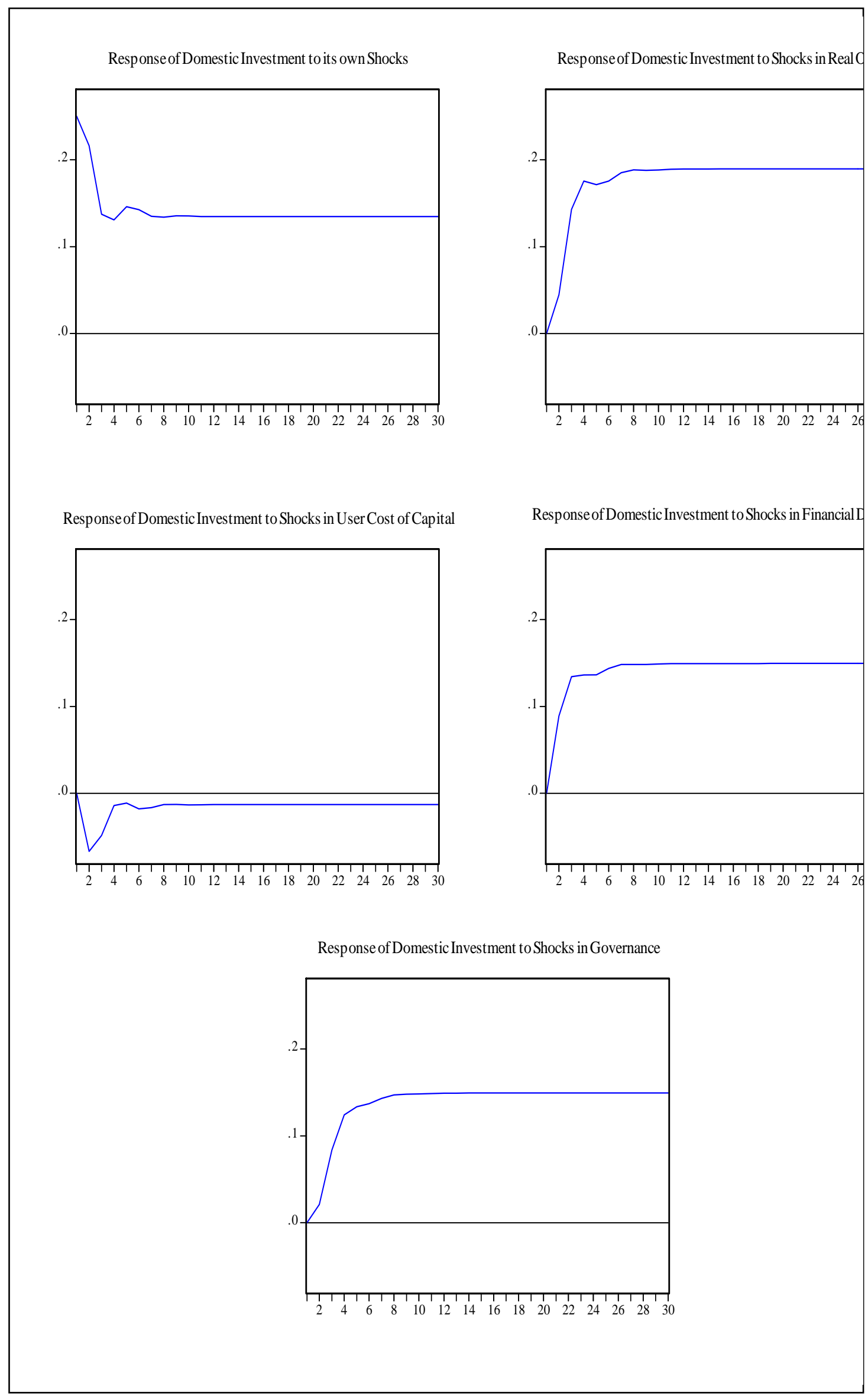


Table 1: Cointegration Test Results

\begin{tabular}{cccccccc}
\hline & \multicolumn{3}{c}{ Trace Test } & \multicolumn{5}{c}{ Maximum Eigenvalue Tests } \\
\hline$H_{o}$ & $H_{1}$ & $\lambda$-Trace & $5 \% \mathrm{CV}$ & $H_{o}$ & $H_{1}$ & $\lambda$-Max & $5 \% \mathrm{CV}$ \\
& & Stat. & & & & & \\
$\mathrm{r}=0$ & $\mathrm{r} \geq 1$ & $66.38^{* *}$ & 60.06 & $\mathrm{r}=0$ & $\mathrm{r}=1$ & 28.46 & 30.44 \\
$\mathrm{r} \leq 1$ & $\mathrm{r} \geq 2$ & 37.93 & 40.17 & $\mathrm{r}=1$ & $\mathrm{r}=2$ & 23.72 & 24.16 \\
$\mathrm{r} \leq 2$ & $\mathrm{r} \geq 3$ & 14.21 & 24.28 & $\mathrm{r}=2$ & $\mathrm{r}=3$ & 12.39 & 17.80 \\
$\mathrm{r} \leq 3$ & $\mathrm{r} \geq 4$ & 1.82 & 12.32 & $\mathrm{r}=3$ & $\mathrm{r}=4$ & 1.39 & 11.22 \\
$\mathrm{r} \leq 4$ & $\mathrm{r} \geq 5$ & 0.43 & 4.13 & $\mathrm{r}=4$ & $\mathrm{r}=5$ & 0.44 & 4.13 \\
\hline
\end{tabular}

Table 2: Estimated Loading Matrices and Weak Exogeneity Tests

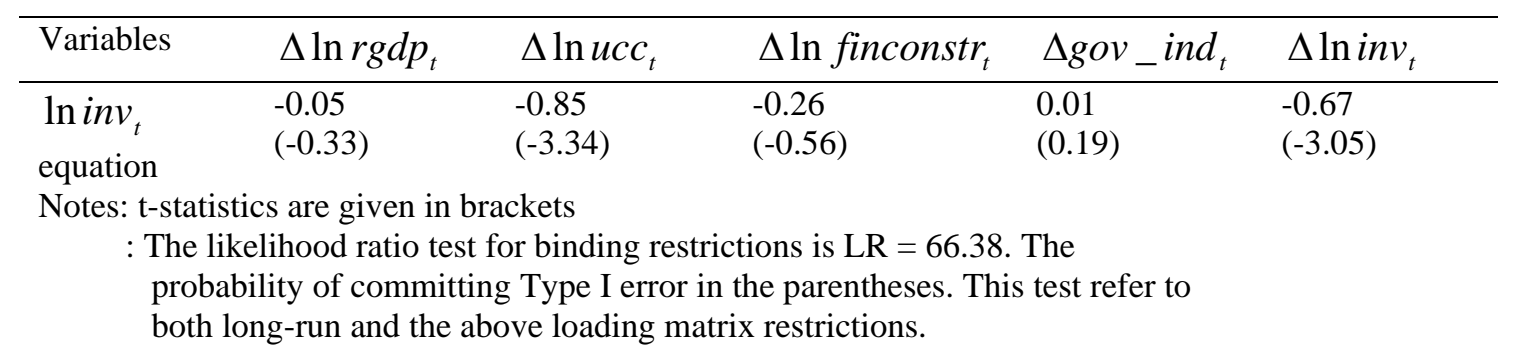


APPENDIX

A. Graphical Representation of all the Variables
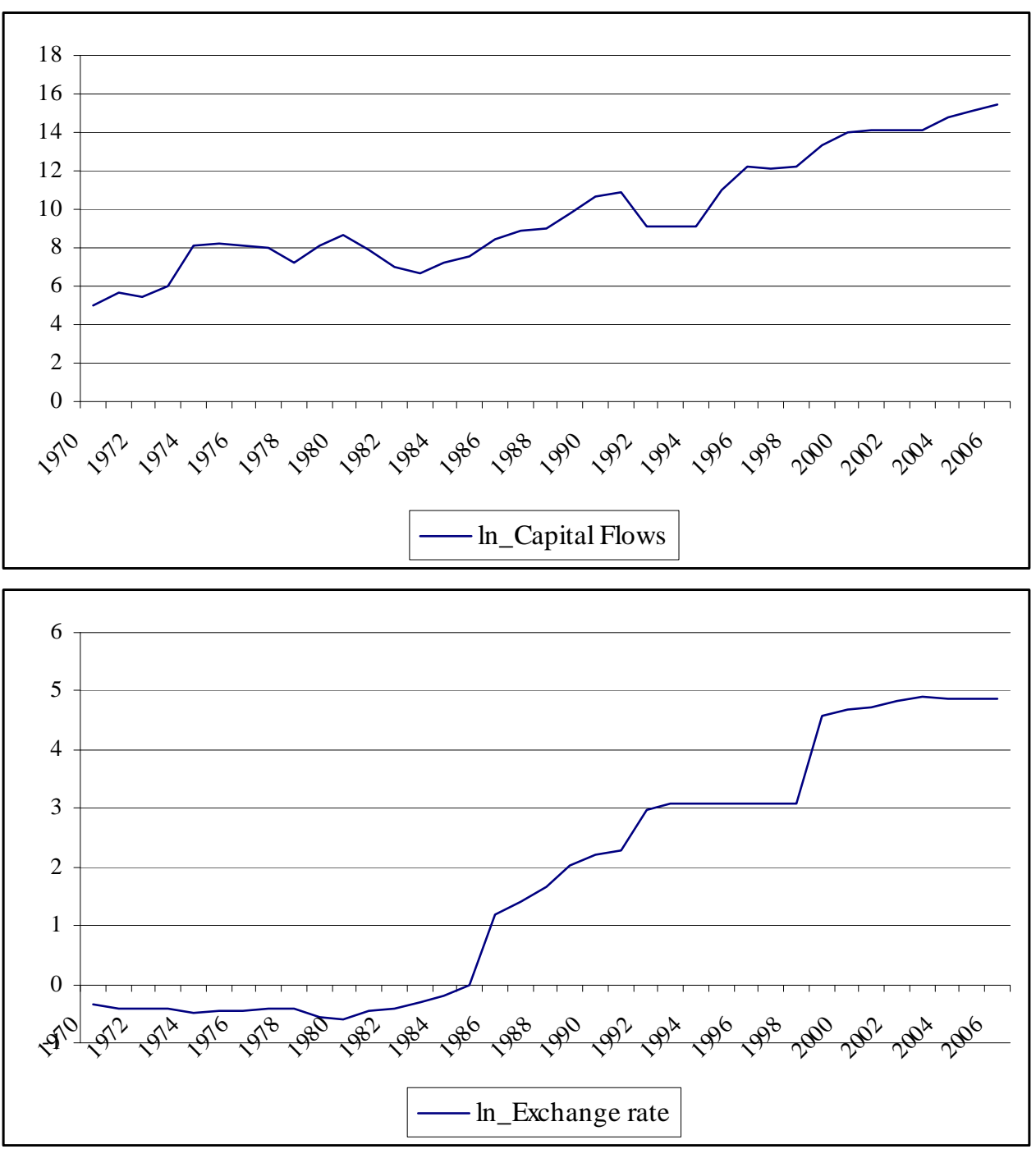

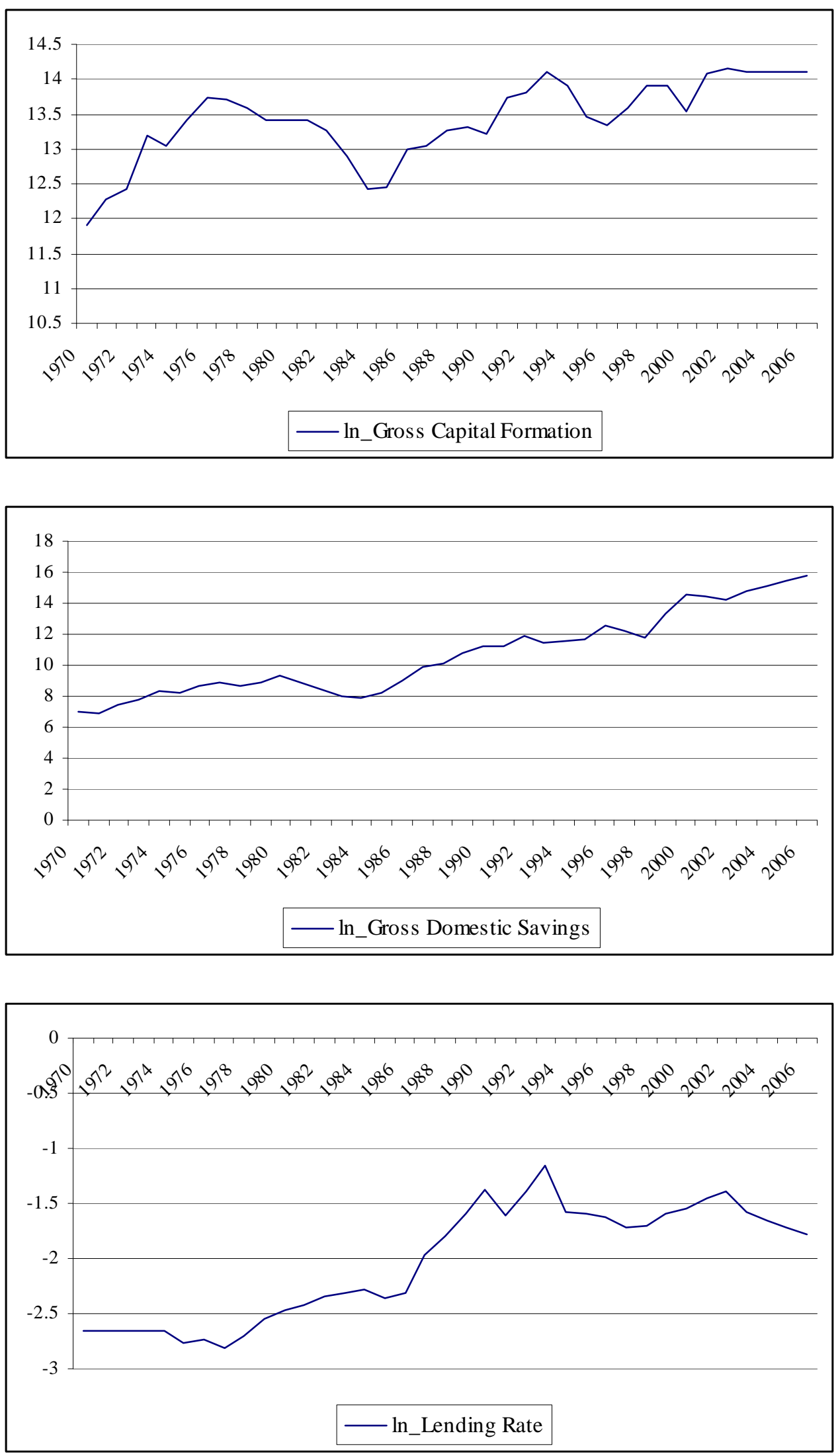

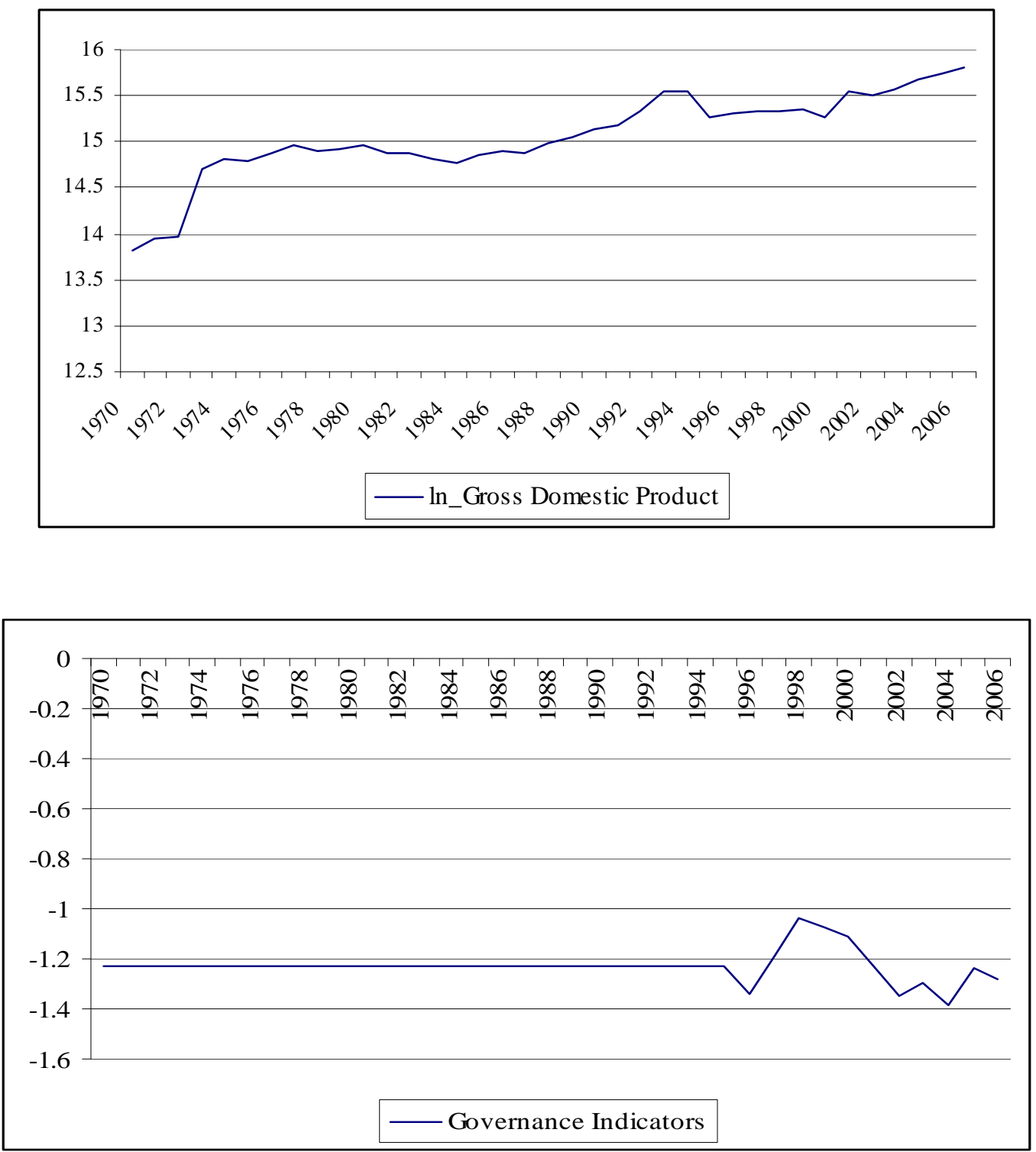

\section{B. Order of Integration for all the Variables}

The univariate characteristics of the data was analysed using the Augmented DickeyFuller (ADF) tests to establish the order of integration, since the actual datagenerating process is not known.

The maximum lag structure that is used follows Said and Dickey (1984), who suggested a lag order equal to $T^{1 / 3}$. $\mathrm{T}$ is the number of observations, which in this case is 37 (years 1970 to 2006). Therefore, the maximum lag structure of 4 is used in the testing procedure. 
Table B1: Augmented Dickey-Fuller tests for non-stationarity, levels, 1970-2006

\begin{tabular}{|c|c|c|c|c|}
\hline Series & Model & Lags & $\tau_{\tau}, \tau_{\mu}, \tau$ & $\phi_{3}, \phi_{1}$ \\
\hline \multirow[t]{3}{*}{ ln_Capital Flows } & Trend & 1 & -2.57 & 2.73 \\
\hline & Constant & 0 & -0.37 & 0.13 \\
\hline & None & 0 & 2.14 & \\
\hline \multirow[t]{3}{*}{ ln_exch } & Trend & 0 & -2.40 & 3.37 \\
\hline & Constant & 0 & 0.21 & 0.04 \\
\hline & None & 0 & 1.71 & \\
\hline ln_Gross Capital & Trend & 0 & -2.82 & 4.39 \\
\hline \multirow[t]{2}{*}{ Formation } & Constant & 0 & $-2.63^{*}$ & $6.93 * *$ \\
\hline & None & 0 & 1.17 & \\
\hline ln_Gross & Trend & 0 & -1.70 & 1.86 \\
\hline \multirow{2}{*}{ Domestic Savings } & Constant & 0 & 0.34 & 0.11 \\
\hline & None & 0 & 3.01 & \\
\hline \multirow[t]{3}{*}{ ln_Lending Rate } & Trend & 0 & -1.11 & 0.91 \\
\hline & Constant & 0 & -1.21 & 1.45 \\
\hline & None & 0 & -1.29 & \\
\hline ln_Gross & Trend & 0 & $-3.33^{*}$ & $6.17^{*}$ \\
\hline \multirow[t]{2}{*}{ Domestic Product } & Constant & 0 & -2.41 & $5.81^{* *}$ \\
\hline & None & 0 & 2.15 & \\
\hline \multirow[t]{3}{*}{ Governance } & Trend & 1 & -2.76 & 3.31 \\
\hline & Constant & 1 & -2.91 & 5.09 \\
\hline & None & 0 & 0.19 & \\
\hline
\end{tabular}

$*(* *)[* * *] \quad$ Significant at a 10(5)[1]\% level.

a At a 10(5)[1]\% significance level, the MacKinnon critical values are -3.18(-3.50)[-4.15] when a trend and a constant are included $\left(\tau_{\tau}\right)$, and -2.60(-2.93)[-3.58] when only a constant is included $\left(\tau_{\mu}\right)$, and $-1.61(-1.95)[-2.62]$ when neither is included $(\tau)$. The standard normal critical value is $-1.697(-2.04)[-2.75]$.

b At a 10(5)[1]\% significance level, the Dickey-Fuller critical values are 5.91(7.24)[10.61] when a trend and a constant are included $\left(\phi_{3}\right)$ and 4.12(5.18)[7.88] when only a constant is included ( $\phi_{1}$ ).

The result of the ADF-test for all the variables used in our estimations is reported in Table B1. The first column shows the list of all the variables that are tested. The second column (model) shows whether the equation that is estimated for the testing purpose involves a trend and a constant (Trend), a constant only (Constant), or neither a constant nor a trend (None). The third column shows the number of lags that are used for each model and they are significant at the 10-percent level. The fourth column is the ADF t-statistic, called $\tau_{\tau}$ (for Trend and a Constant), $\tau_{\mu}$ (for only Constant), and $\tau$ (for neither Trend nor Constant). The last column is the F-statistic $\phi_{3}\left(\phi_{1}\right)$, testing whether the trend (constant) is significant under the null hypothesis of no unit root.

From the result, it is clear that most of the variables are non-stationary [I(1)] in level form. 


\section{Reduced-Form VAR Diagnostic Tests}

All the roots have modulus less than one and lie inside the unit circle. Table C1 presents other diagnostics tests for the VAR. The VAR passed all the diagnostic tests, revealing a well-specified model.

Table C1: Diagnostic Test on the Reduced-Form VAR

\begin{tabular}{ccccc}
\hline$H_{1}$ & $H_{0}$ & Test & Statistic & Prob. \\
\hline Serial Correlation & $\begin{array}{c}\text { No Serial } \\
\text { Correlation }\end{array}$ & $\begin{array}{c}\text { LM-Test- } \chi^{2} \\
(\text { lag 2) }\end{array}$ & 25.01 & 0.46 \\
\hline Normality & Normally & JB-Joint & 12.15 & 0.28 \\
& Distributed & Kurtosis-Joint & 4.26 & 0.51 \\
& Error Term & Skewness-Joint & 7.89 & 0.16 \\
\hline Heteroschedasticity & No & $\chi^{2}$ & 215.75 & 0.15 \\
& Heteroschedasticity & & & \\
\hline
\end{tabular}

\section{Vector Error Correction Estimates (Governance Indicator)}

\begin{tabular}{|c|c|c|c|c|c|}
\hline Cointegrating Eq: & CointEq1 & & & & \\
\hline LN_GCF(-1) & 1.000000 & & & & \\
\hline LN_RGDP(-1) & $\begin{array}{r}-0.953554 \\
(0.07343) \\
{[-12.9861]}\end{array}$ & & & & \\
\hline LN_UCC $(-1)$ & $\begin{array}{c}0.189700 \\
(0.07238) \\
{[2.62087]}\end{array}$ & & & & \\
\hline LN_FINCONSTR(-1) & $\begin{array}{r}-0.165414 \\
(0.06303) \\
{[-2.62419]}\end{array}$ & & & & \\
\hline GOV_IND(-1) & $\begin{array}{r}-1.867154 \\
(0.66970) \\
{[-2.78803]}\end{array}$ & & & & \\
\hline Error Correction: & D(LN_GCF) & $\mathrm{D}\left(\mathrm{LN} \_R G D P\right)$ & $D\left(L N \_U C C\right)$ & $\begin{array}{c}\mathrm{D}(\mathrm{LN} \text { _FINCON } \\
\text { STR })\end{array}$ & $\mathrm{D}(\mathrm{GOV}$ IIND) \\
\hline CointEq1 & $\begin{array}{r}-0.672564 \\
(0.22084) \\
{[-3.04549]}\end{array}$ & $\begin{array}{r}-0.049062 \\
(0.14878) \\
{[-0.32977]}\end{array}$ & $\begin{array}{r}-0.851318 \\
(0.25456) \\
{[-3.34430]}\end{array}$ & $\begin{array}{r}-0.256759 \\
(0.46083) \\
{[-0.55717]}\end{array}$ & $\begin{array}{c}0.011327 \\
(0.05793) \\
{[0.19554]}\end{array}$ \\
\hline $\begin{array}{l}\text { R-squared } \\
\text { Adj. R-squared }\end{array}$ & $\begin{array}{l}0.381814 \\
0.249346\end{array}$ & $\begin{array}{l}-0.025478 \\
-0.245223\end{array}$ & $\begin{array}{l}0.416859 \\
0.291900\end{array}$ & $\begin{array}{r}0.033094 \\
-0.174101\end{array}$ & $\begin{array}{r}0.038261 \\
-0.167826\end{array}$ \\
\hline
\end{tabular}




\begin{tabular}{lrrrrr} 
Sum sq. resids & 1.747755 & 0.793238 & 2.322197 & 7.610388 & 0.120243 \\
S.E. equation & 0.249840 & 0.168315 & 0.287985 & 0.521344 & 0.065532 \\
F-statistic & 2.882301 & -0.115941 & 3.335966 & 0.159723 & 0.185656 \\
Log likelihood & 2.784927 & 16.60929 & -2.188245 & -22.96075 & 49.62497 \\
Akaike AIC & 0.240861 & -0.549102 & 0.525043 & 1.712043 & -2.435712 \\
Schwarz SC & 0.551931 & -0.238033 & 0.836112 & 2.023113 & -2.124643 \\
Mean dependent & 0.052633 & 0.053043 & 0.153181 & 0.258146 & -0.001429 \\
S.D. dependent & 0.288364 & 0.150834 & 0.342234 & 0.481140 & 0.060640 \\
\hline \hline & \\
\hline \multirow{2}{*}{ Determinant resid covariance (dof adj.) } & $4.73 \mathrm{E}-08$ & & & \\
Determinant resid covariance & $1.55 \mathrm{E}-08$ & & & \\
Log likelihood & 66.37763 & & & \\
Akaike information criterion & -1.507293 & & & \\
Schwarz criterion & 0.270248 & & & \\
\hline \hline
\end{tabular}

\section{E. Robustness Check on Governance Indicator}

In order to validate the long-run relationship of the investment function adopted in this study, a robustness check on the role of governance is performed by using alternative institutional indices which cover the period of the study. The average value of the combined political right and civil liberty indices (cl_pr), from the Freedom House Political Right Index (FHPRI), is used as a measure of governance. The index ranges from 1 to 7 , with the low values representing 'total freedom', the median values 'partial freedom' and the high values 'no freedom'. Higher values represent worse governance, which is a different interpretation from the Kaufmann Worldwide Governance Indicators used in the study.

The result from this estimation (as presented in the Table below) confirms that the level of governance plays a significant role in the long-run investment decisions of firms. The diagnostic test shows that the trace test identified one cointegrating vector, while the maximum eigenvalue test found no cointegration for a model with no trend and intercept in the cointegrating equation.

As mentioned earlier, Kaufmann et al (1999a) is adopted in the study since it covers a broader range of policy and institutional factors (governance) than the FHPRI.

Vector Error Correction Estimates (FHPRI)

\begin{tabular}{l} 
Vector Error Correction Estimates \\
Sample (adjusted): 19722006 \\
Included observations: 35 after adjustments \\
Standard errors in ( ) \& t-statistics in [ ] \\
\hline Cointegrating Eq: CointEq1
\end{tabular}




\begin{tabular}{|c|c|c|c|c|c|}
\hline LN_GCF(-1) & 1.000000 & & & & \\
\hline \multirow[t]{3}{*}{ LN_RGDP(-1) } & -0.806590 & & & & \\
\hline & $(0.05521)$ & & & & \\
\hline & {$[-14.6093]$} & & & & \\
\hline \multirow[t]{3}{*}{ LN_UCC(-1) } & 0.085888 & & & & \\
\hline & $(0.09324)$ & & & & \\
\hline & [ 0.92114] & & & & \\
\hline \multirow[t]{3}{*}{ LN_FINCONSTR(-1) } & -0.138839 & & & & \\
\hline & $(0.08750)$ & & & & \\
\hline & {$[-1.58673]$} & & & & \\
\hline \multirow[t]{3}{*}{ LN_CL_PR(-1) } & 0.568668 & & & & \\
\hline & $(0.22671)$ & & & & \\
\hline & [ 2.50830] & & & & \\
\hline Error Correction: & D(LN_GCF) & D(LN_RGDP) & D(LN_UCC) & $\begin{array}{c}\text { D(LN_FINCON } \\
\text { STR })\end{array}$ & $\mathrm{D}\left(\mathrm{LN} \_\mathrm{CL} P \mathrm{PR}\right)$ \\
\hline \multirow[t]{3}{*}{ CointEq1 } & -0.467595 & -0.111882 & -0.717042 & -0.626215 & -0.061446 \\
\hline & $(0.15519)$ & $(0.10176)$ & $(0.19785)$ & $(0.31391)$ & $(0.16229)$ \\
\hline & {$[-3.01300]$} & {$[-1.09944]$} & {$[-3.62411]$} & {$[-1.99487]$} & {$[-0.37862]$} \\
\hline R-squared & 0.376723 & 0.020506 & 0.280779 & 0.084001 & 0.094131 \\
\hline Adj. R-squared & 0.269262 & -0.148372 & 0.156775 & -0.073929 & -0.062053 \\
\hline Sum sq. resids & 1.762148 & 0.757669 & 2.864096 & 7.209700 & 1.926980 \\
\hline S.E. equation & 0.246503 & 0.161637 & 0.314264 & 0.498608 & 0.257774 \\
\hline F-statistic & 3.505656 & 0.121427 & 2.264278 & 0.531888 & 0.602693 \\
\hline Log likelihood & 2.641403 & 17.41215 & -5.858680 & -22.01424 & 1.076544 \\
\hline Akaike AIC & 0.191920 & -0.652123 & 0.677639 & 1.600813 & 0.281340 \\
\hline Schwarz SC & 0.458551 & -0.385492 & 0.944270 & 1.867445 & 0.547971 \\
\hline Mean dependent & 0.052633 & 0.053043 & 0.153181 & 0.258146 & 0.011585 \\
\hline S.D. dependent & 0.288364 & 0.150834 & 0.342234 & 0.481140 & 0.250130 \\
\hline \multicolumn{2}{|c|}{ Determinant resid covariance (dof adj.) } & 7.39E-07 & & & \\
\hline \multicolumn{2}{|c|}{ Determinant resid covariance } & 2.89E-07 & & & \\
\hline \multicolumn{2}{|l|}{ Log likelihood } & 15.19801 & & & \\
\hline \multicolumn{2}{|l|}{ Akaike information criterion } & 1.131542 & & & \\
\hline \multicolumn{2}{|l|}{ Schwarz criterion } & 2.686890 & & & \\
\hline
\end{tabular}

